\title{
HUMAN RESOURCES OPTIMIZATION AND UTILIZATION OF ACCRUAL BASED ACCOUNTING INFORMATION TECHNOLOGY ON PERFORMANCE OF SURAKARTA CITY GOVERNMENT FINANCIAL REPORTING
}

\author{
Adinna Hapsari $^{{ }^{*}}$, Siti Nurlaela ${ }^{2}$, Kartika Hendra Titisari ${ }^{3}$ \\ ${ }^{1,2,3}$ Accounting Departement, Faculty of Economics, Islam Batik University of Surakarta \\ Jl. KH. Agus Salim No. 10 Surakarta \\ E-mail: dinnapark95@gmail.com
}

Abstract : This research is conducted by explaining about two research variables, namely Optimization of Human Resources and Utilization of Accrual-Based Accounting Information Technology has a positive influence on Financial Reporting Performance. The research sample was employees of the Badan Pendapatan, Pengelolaan, Keuangan, dan Aset Daerah (BPPKAD). Data collection is done by taking 35 respondents from BPPKAD employees using questionnaires as research instruments. The sampling technique uses a purposive / judgment sampling method which was developed from the results of research by Umar Sekaran (2006). The results of the study show that H1 research has a positive influence on the financial statement performance variables, as well as $H 2$ which has a positive influence on the performance of financial statements. In the $F$ test shows the results that the two variables have a simultaneous influence on $Y$.

Keywords: optimization, human resources, utilization, accrual based accounting system, accounting information system.

\section{INTRODUCTION}

The background of this research is changes to the Minister of Home Affairs Regulation No. 64/2013 concerning the Implementation of Accrual-Based Government Accounting Standards in the Regional Government issued to implement the provisions of Article 7 paragraph (3) Government Regulation Number 71 of 2010 concerning Government Accounting Standards, while in Article 4 paragraph (1) The Government applies Accrual-based Government Accounting Standards (SAP) (Nurlinda, 2017).

PSAP No.10 states that the accounting base used in government financial statements is the cash base for recognition of income, expenditure, transfers and financing, while for estimates that exist in government balance sheets such as recognition of assets, liabilities and equity funds used accrual basis. (PSAP No. 71 of 2010).

\section{LITERATURE REVIEW Human Resources Optimization}

Prihantoro, (2012), in his research said the current era of globalization, which is characterized by changes that are so rapid, an organization or institutional institution is required to make adjustments - adjustments in all aspects of the organization. Human resources have a very important role, in their interaction with capital, material, method and 


\section{Vol-3, Issue-1, 2019 (IJEBAR)}

\section{ISSN: 2614-1280}

http://www.jurnal.stie-aas/ijebar

machine factors. Existing complexity can determine human quality. Therefore it requires us to always be careful and pay attention to every aspect. (Parjanti, Titisari, \& Nurlaela, 2014).

\section{Use Of Accrual-Based Accounting Information Technology}

According to Permatasari in 2011, presented several technological benefits based on systems, including: (1) Fast data processing; (2) High accuracy in data; (3) Efficiency of human resources; (4) and easy access to information.

In 2009, Namani stated that "Information technology has a very real influence in many industries and all aspects of the economy, while the continuation of businesses and companies to consider change. The use of technology is undergoing a company regulatory revolution, the result is a corporate transformation structure. Modern business is not possible without the help of information technology which has a significant influence on the operations of small and medium size companies."

In accordance with Government Regulation (PP) Number 71 of 2010 concerning Government Accounting Standards, Article 4 paragraph (1) The Government applies Accrual-based Government Accounting Standards (SAP).

Accrual-based SAP is SAP that recognizes income, expenses, assets, debt, and equity in accrual-based financial reporting, and recognizes revenue, expenditure, and financing in reporting budget execution based on the basis stipulated in the APBN / APBD. Accrualbased SAP is listed in Appendix I of PP 71 of 2010.

\section{Regional Government Financial Report Concept}

According to the Republic of Indonesia Minister of Home Affairs Regulation (Permendagri RI) Number 64 of 2013 and SAP No. 70 concerning the Implementation of Accrual-Based Government Accounting Standards in Regional Governments Chapter 1 Article 1, items 16 d.d22 mention:
a. Budget Realization Report (LRA)
b. Balance Change Report
c. Balance
d. Operational Report (LO)
e. Cash Flow Statement (LAK)
f. Change of Equity Report (LPE)
g. Notes to Financial Statements (CaLK).

\section{Framework}

As the development of existing science and information technology, regional instruments that guarantee the creation of good community activities will certainly follow by optimizing existing human resources and developing the utilization of information technology that works well. Accrual-based information technology is a Government Accounting Standard (SAP) in accordance with Government Regulation (PP) Number 71 of 2010 article 4 paragraph (1).

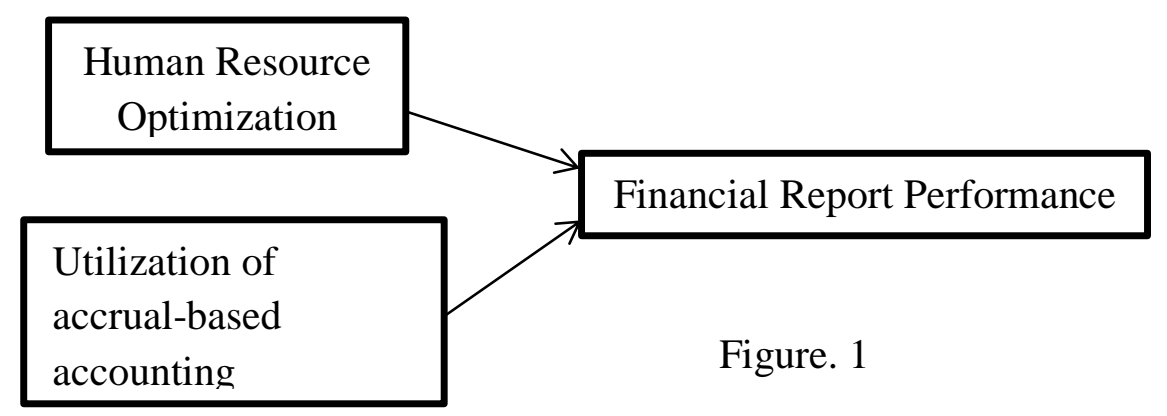




\section{Hypothesis}

1) Effects of Optimizing Human Resources on Financial Reporting Performance

H1: Optimization Human resources have a significant positive effect on financial reporting performance.

2) Effect of Information Technology Utilization on Financial Reporting Performance

$\mathrm{H} 2$ : The use of information technology has a significant positive effect on financial reporting performance.

\section{RESEARCH METHODS}

Research design In this study the data to be analyzed are primary data. Primary data comes from interview answers and questionnaires as research instruments that are measured by a Likert scale and sent directly to employees and management, income, financial and assets (BPPKAD) IKotaISurakarta. Population and Sampling The population in this study are local government organizations (OPD) in Surakarta, namely the Regional Management, Revenue, Finance and Asset Management (BPPKAD) of the City of Surakarta. Sampling is done by taking 33 respondents from Employees and Management, Regional Income, Finance and Assets (BPPKAD) of Surakarta City with sampling techniques using purposive sampling method which was developed from the results of research by Umar Sekaran (2006).

\section{RESEARCH RESULTS AND DISCUSSION \\ Instrument Test \\ Validity test}

Based on the table, it is known that all questionnaire items are valid, namely items $1, \mathrm{I} 2,13$, I4, I5, I6, I7, and 8, so that the items may be used as instruments for collecting data.

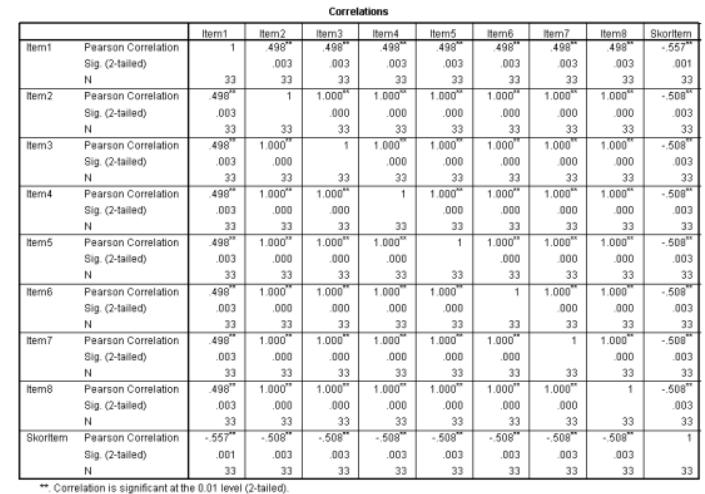

Reliability Test

Reliability Statistics

\begin{tabular}{|c|r|}
\hline $\begin{array}{c}\text { Cronbach's } \\
\text { Alpha }\end{array}$ & N of ltems \\
\hline 1.000 & 8 \\
\hline
\end{tabular}

This test is used to measure the stability of the measuring instrument. Questionnaires are said to be reliable if they can provide relatively the same results when remeasuring different objects at different times.

Reliability Statistics
\begin{tabular}{|c|r|}
\hline $\begin{array}{c}\text { Cronbach's } \\
\text { Alpha }\end{array}$ & N of ltems \\
\hline .983 & 8 \\
\hline
\end{tabular}

Conbrach's alpha in the human resource optimization questionnaire The HR optimization questionnaire obtained a value of 0.983 , the accrual-based accounting 
International Journal of Economics, Business and Accounting Research (IJEBAR)

Peer Reviewed - International Journal

Vol-3, Issue-1, 2019 (IJEBAR)

ISSN: 2614-1280

http://www.jurnal.stie-aas/ijebar

information technology utilization questionnaire obtained a value of 1 , and in the financial statement performance questionnaire obtained a value of 1 .

\section{Reliability Statistics}

\begin{tabular}{|c|r|}
\hline $\begin{array}{c}\text { Cronbach's } \\
\text { Alpha }\end{array}$ & N of Items \\
\hline 1.000 & 8 \\
\hline
\end{tabular}

From the reliability testing carried out, the three showed more than 0.60 , so it can be concluded that the three questionnaires passed the reliability test.

Classic assumption test

Normality test

Known the significance value of each variable is greater than 0.05 , so it can be concluded that the data from each variable has a distribution that does not deviate from the normal distribution.

\section{Multicollinearity Test}

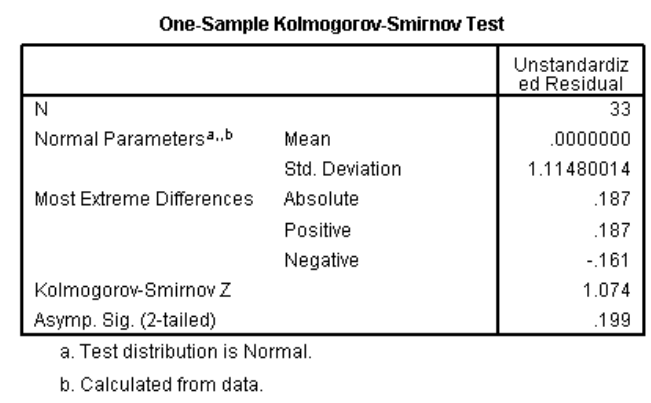

Based on the table of the results of the multicollinearity test above, it shows that for each independent variable the value of tolerance obtained when the study is more than 0.1 and for each independent variable the research for VIF values is below the value of 10 . Thus the results of the study are free of multicollinearity.

Heterokesdatisitas Test

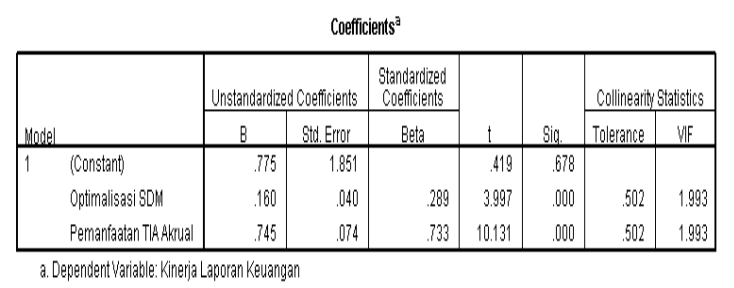

Based on decision making if the value of Sig. $>0.05$ then there is no Heterokesasticity, so it can be concluded that the results of the above variables do not occur heteroscedasticity.

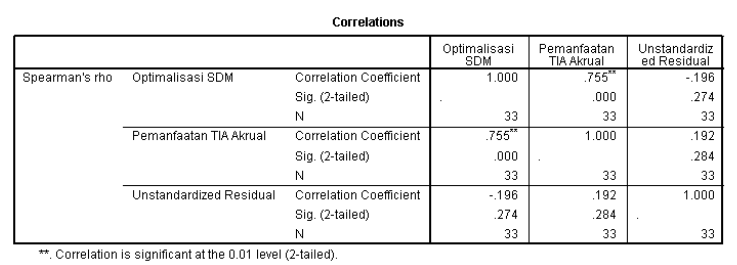

Hypothesis testing Multiple linear regression

The regression equation obtained is as follows:

$\mathrm{Y}=0.678+0.160 \mathrm{X} 1+0.745 \mathrm{X} 2+\mathrm{e}$

The interpretations of multiple linear equations are as follows:

a. From the multiple regression equation above it can be concluded that all the dependent variables are equal to 0 , then the financial reporting performance will change by 0.678 .

b. The HR Optimization Coefficient is 0.160 , stating that each addition of value to HR Optimization will give a score of 0.160. HR optimization has significant influence on the performance of financial statements. This can be seen from the significance of $\mathrm{HR}$ Optimization of 0,000 which is smaller than 0.05 .

c. The Accrual Base Information Technology Coefficient is 0.745 , stating 
that each addition of value in Accrual Base Information Technology will give a score of 0.745. Accrual Base Information Technology has a significant influence on the performance of financial statements. This can be seen from the significance value of the Accrual Base Information Technology of 0,000 which is smaller than 0.05 .

\section{Model Feasibility Test}

Based on the OutputI, we know that the Significant Value I for the effect of X1I and IX2I is the same as the ISI facing IIY is I0,000I <0.05I and the Fcount is 175,190> 3,30 so it can be concluded that there is a simultaneous influence of $\mathrm{X} 1$ and $\mathrm{X} 2$ on $\mathrm{Y}$.

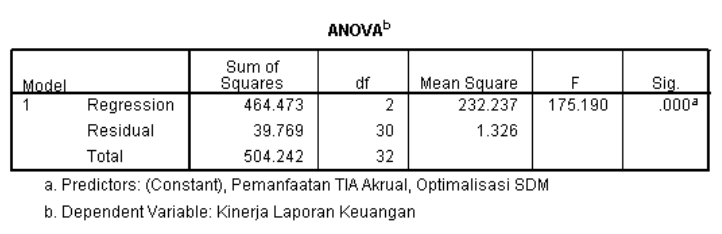

T test

Hypothesis I: There is an influence between optimization of human resources (X1) on financial reporting performance $(\mathrm{Y})$.

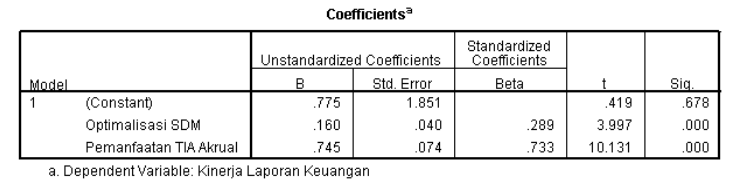

because $\mathrm{t}$ count $>\mathrm{t}$ table, which is 3.997> 2.04277 and significance value $<0.005$, which is 0,000 .

Hypothesis II: There is an influence between accrual-based accounting information technology (X2) on financial reporting performance $(\mathrm{Y})$.

because $\mathrm{t}$ count $>\mathrm{t}$ table, which is 10.131> 2.04277 and a significance value of $<0.005$, which is 0,000 . There is a significant positive effect on accrual-based accounting technology on the performance of financial statements.

\section{Determination Test $\left(\mathrm{R}^{2}\right)$}

Based on the results of the table above, there is an Adjust R Square value of 0.916, which shows that the performance of financial statements can be explained by the variable optimization of HR, and accrual basis accounting information technology amounting to $91.6 \%$, while the remainder of I8.4\% influences other factors outside the careful model.

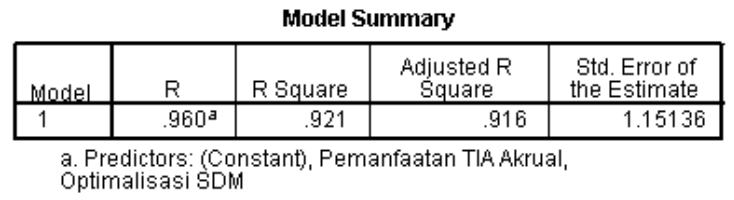

Based on hypothesis testing and explanation of what has been done, the findings can be concluded that the optimization of human resources has a positive and significant effect on the performance of financial statements. Accrual-Based Accounting Information Technology has a positive and significant effect on the performance of financial statements. Variable optimization of human resources and utilization of accrual-based accounting information technology together have a positive and significant effect so that it can concluded that variable optimization of human resources and utilization of accrualbased information technology support each other in the creation of good financial statement performance.

\subsection{Suggestion}

The authors submit several suggestions in the study as follows:

a. There is a system of renewal in terms of improving the potential of human resources in the BPPKAD of Surakarta City. 
International Journal of Economics, Business and Accounting Research (IJEBAR)

Peer Reviewed - International Journal

Vol-3, Issue-1, 2019 (IJEBAR)

ISSN: 2614-1280

http://www.jurnal.stie-aas/ijebar

b. Provide adequate facilities during the activities related to the preparation of financial statements.

c. Giving workshops in accordance with the level of experience, and education possessed by human resources.

\section{REFERENCES}

Char, A. K Yasoa, R. M H, Zakiah. (2010). Small and Medium Enterprise Competing in The Global Business Environtment : A Case of Malaysia. International Business Research, 3(1),1.

Firdaus; , Nadirsyah; Fahlevi, Heru. (2015). Pengaruh Kualitas Sumber Daya Manusia, Pemanfaatan Teknologi Informasi dan Penerapan Kebijakan Akuntansi Terhadap Kualitas Keuangan Pemerintah Kota Banda Aceh. Jurnal Magister Akuntansi, 4(1),4.

Hardyansyah; Khalid, Ansyarif. (2016). Pengaruh Kompetensi Sumber Daya Manusia dan Pemanfaatan Teknologi Informasi Terhadap Kualitas Laporan Keuangan Dengan Sistem Pengendalian Intern Sebagai Variabel Moderasi Pada

SKPD Kabupaten Polewali Mandar. Jurnal Ilmiah Akuntansi Peradaban, 1(1), 5 .

Internatonal Financial Reports Standards. (2012). International Financial Reports Standards.

Mardiasmo;. (2006). Perwujudan Transparansi dan Akuntabilitas Publik Melalui Akuntansi Sektor Publik : Suatu Sarana Good Governance. Jurnal Akuntansi Pemerintah, 2(1), 10.

Nofan; Al - Oleemat, Hamid Mohammed. (2014). Impact Of Computerized Accounting Information Systems' Effectiveness in Incncreasing The Efficiency Of Human Capital : Field Study in The Financial Department In The Public Jordanian Universities. Interdiciplinary Journal of Contemporary Research in Business, 6(5),4.

Ramdany. (2015). Influence The Quality of Accounting Information Systems and The Effectiveness of Internal Control On Financial Report Quality. Research Journal of Finance and Accounting , 6(6), 4. 